\author{
Z.K. Kulsharipova ${ }^{1}$, S.N. Tokabayeva ${ }^{1}$, L.S. Syrymbetova ${ }^{2}$ \\ ${ }^{I}$ Pavlodar State Pedagogical University Pavlodar, Kazakhstan; \\ ${ }^{2}$ Ye.A. Buketov Karaganda State University, Kazakhstan \\ (E-mail: KulsharipovaZK@mail.ru)
}

\title{
Interpersonal conflicts in adolescence
}

\begin{abstract}
Conflict is an essential and unavoidable human phenomenon because where there is human interaction; there is a likelihood of personal likes and dislikes. These agreements and disagreements among individuals and groups lead them to conflicts. Conflicts are neither constructive nor disruptive but the ways these are handled make them either positive or negative. Schools, like other human organizations, are prone to one or other type of conflict. Various conflict management strategies are adopted for handling conflict; the most important among these are: mediation, negotiation, avoidance, collaborating etc. Main thrust of this article is on the exploration of the nature of conflicts in schools, its causes and techniques adopted for its management and redressal. Conflict arises when there is a zone of disagreement - 371.513 The solution to this problem involves the achievement of several objectives in the process of learning technology integration of sociopedagogical sphere and scope of psychological services: mastering theoretical knowledge in the scope necessary and sufficient for realization of professional activity of teachers - psychologists. To change the attitude to conflicts for a teenager almost means to change the Outlook on life. You need to look for a working solution that will change the specific situation, behavior and thinking.
\end{abstract}

Keywords: a teenager, support and correction, mastering new rules and regulations, conflict, interpersonal relations, human phenomenon, personal likes and dislikes.

The problem of studying interpersonal conflicts among teenagers is relevant today. Knowledge of the features of interpersonal conflicts between adolescents and their peers, the causes of their occurrence and ways to manage them is an important component in the professional training of a teacher-psychologist for the prevention of deviant behavior [1-3].

Frequent causes of conflicts with peers are quarrels over the second half; insults, gossip, denunciations, envy; mutual misunderstanding of teenagers. As noted in the review of school conflicts AI Shipilov, the most common among students conflicts of leadership, which reflects the struggle of two or three leaders and their groups for supremacy in the classroom $[4,5,6,7]$. According to the observations of psychologists O. Sitkovskaya and O. Mikhailova, the path to leadership, especially in the adolescent environment, is associated with a demonstration of superiority, cynicism, cruelty, ruthlessness $[8,9,10]$.

Conflicts between teenagers at school arise also because of misdemeanors, violations of generally accepted norms in the behavior of students. Students allow such violations of the norms of behavior in school, such as Smoking, drinking alcohol, using obscene language, lying, petty theft, fighting.

Interpersonal and inter-group conflicts have a negative impact on all processes of life of the school. Conflicts between students negatively affect both the conflicting themselves and the entire class, in a class where there is an unfavorable socio-psychological climate, children do not learn the program material, simple resentment can, in the end, lead to cruelty against their peers, etc.

It is extremely necessary to deal with timely diagnostics and prevention of conflicts in school collectives.

First, conflict prevention will undoubtedly improve the quality of the educational process. Students will spend their intellectual and moral strength not on fighting opponents, but on their main activities.

Secondly, conflicts have a noticeable negative impact on the mental state and mood of the conflicting. The stress of conflict can cause dozens of serious illnesses. Therefore, timely preventive measures should have a positive impact on the psychological and physical health of students.

Third, it is at school that a child or teenager develops skills for resolving contradictions in interpersonal interaction that occur in the life of every person [9].

Interest in the problem of conflicts was formed in Russian science for a long time. There are a number of approaches to defining the concept of «conflict» in psychology. A. ya. Antsupov and A.I. Shipilov propose the definition of conflict as a way to resolve significant contradictions that arise in the process of interaction, which consists in countering the subjects of the conflict and is usually accompanied by nega- 
tive emotions [7]. N.V. Grishina considers the conflict as a confrontation of two principles, which manifests itself in the activity of the parties aimed at overcoming the contradiction, and each of the parties to the conflict is represented by an active subject (s) [11].

A.A. Ershov defines interpersonal conflict as a clash of personalities due to the incompatibility of needs, motives, goals, attitudes, attitudes, behavior in the process and as a result of communication of these individuals

Currently, the main attention in the scientific development of theories of conflicts in the school environment is paid to the following areas: conflicts in a group of students (V.M. Afonkova, E.A. Timokhovets); the essence of conflicts, their causes in adolescent groups (B.S. Alishev, T.A. Chistyakova); conflicts between students and teachers (O.N. Lukashenok, N.E. Shchurkova).

Among the monographic publications I would like to highlight the work of A. ya. Antsupov «prevention of conflicts in the school team» (M., 2003); «Social psychology» edited by A.L. Zhuravlev (M., 2002).

The great advantage of these works is that they give a significant place to the study of the causes of conflict situations in the school, as well as their prevention. In addition, domestic and foreign authors devoted their works to this problem: N.V. Grishina, V.I. Zhuravlev, E.M. Dubovskaya, G.I. Kozyrev, H. Cornelius, L.A. Petrovskaya, A.V. Petrovsky and others.

A major role in the conflict played by the so-called conflictogenes. Conflictogenes - words, actions (or inaction) that could lead to conflict. The great danger stems from ignoring a very important pattern-the escalation of conflict-causing factors. It consists in the following: we try to respond to the conflictogen in our address with a stronger conflictogen, often as strong as possible among all possible ones.

It is very important to know the formula of the conflict and to use it effectively. It looks like this:

Conflict - conflict situation + incident

Conflict is an open confrontation as a result of mutually exclusive interests and positions.

A conflict situation is an accumulated contradiction that contains the true cause of the conflict.

An incident is a combination of circumstances that give rise to a conflict.

The formula shows that the conflict situation and the incident are independent of each other, i.e. neither of them is a consequence or manifestation of the other.

To resolve a conflict means to eliminate the conflict situation and to exhaust the incident. It is clear that the first is more difficult to do, but also more important. Unfortunately, in practice, in most cases, the case is limited only to the exhaustion of the incident. But often we also use a technique-suppressionwithdrawal from the implementation of goals under the influence of external coercion, when frustration is driven deep and can at any time come out in the form of aggression [12].

Let's consider the features of conflicts in class groups.

In General education schools, the foundations of human behavior in the future in pre-conflict and conflict situations are laid. In order to prevent conflicts, it is necessary to have an idea of how they arise, develop and end in school groups, what their features and causes are.

Consider one of the most common in educational activities - the conflict between students.

As noted in the review of school conflicts prepared by A.I. Shipilov, the most common among students are leadership conflicts, which reflect the struggle of two or three leaders and their groups for supremacy in the classroom. In the middle classes, there is often a conflict between a group of boys and a group of girls. There may be a conflict of three or four teenagers with the whole class, or a confrontation between one student and the class. According to the observations of psychologists [13], the path to leadership, especially in the adolescent environment, is associated with a demonstration of superiority, cynicism, cruelty, ruthlessness.

In the early stages of socialization, aggression may occur accidentally, but if the goal is successfully achieved in an aggressive way, there may be a desire to re-use aggression to get out of various difficult situations. If you have the appropriate personality foundations important not to become aggression as a way of achieving, and aggression as an end in itself, it becomes an independent motive for the behavior, causing hostility towards others at a lower level of self-control.

Besides, conflicts of the teenager in the relations with schoolmates are caused by feature of age formation of moral and ethical criteria of an assessment of the peer and the requirements connected with it to its behavior.

In pedagogical conflictology [14], experts have identified the main factors that determine the features of conflicts between students. 
First, the specificity of conflicts between students is determined by age psychology. The age of the student has a significant impact on the causes of conflicts, as well as on the features of their development and ways of completion. We know that the period of study at school is the stage of the most intensive human development.

School covers a significant part of childhood. And here the main factor that determines the features of conflicts between students is the process of socialization of students. Socialization is the process and result of assimilation of active reproduction of social experience by an individual, manifested in communication and activity. Socialization of students occurs naturally in everyday life and activities, as well as purposefully-as a result of pedagogical influence on students at school.

One of the ways and manifestations of socialization in schoolchildren is interpersonal conflict. In the course of conflicts with others, the child, the teenager realize how it is possible and how it is impossible to act in relation to peers, teachers, parents.

Secondly, the features of conflicts between students are determined by the nature of their activities in the school, the main content of which is learning.

Third, the specifics of conflicts between students in modern conditions are determined by the current way of life, changes in the socio-economic situation, and as a result, inequality in the material support of the family.

Consider the process of violation of interpersonal relationships with classmates in adolescence

Age - a certain qualitatively original, limited in time stage of development of the individual. It is in adolescence that communication with peers becomes of great importance. Relationships with peers are at the heart of a teenager's personal life, largely determine all other aspects of his behavior and activities, including educational [8].

For teenagers, it is important not only to communicate with their peers at school, but to take a satisfying position among their classmates. This position, able to satisfy the desire of a teenager to self-esteem, is different for each student. Some seek to take the position of a leader in the group, others-to get recognition and respect from friends, others-to become an indisputable authority in any business, etc. in any case, the need for a certain position among peers becomes the dominant motive in behavior and learning, which affects the effectiveness and efficiency of the learning process.

To take a leading position in the class of a teenager helps his psychological characteristics: a high need for the development of the surrounding reality, the desire for mental stress and physical labor, various forms of activity.

Leaders rate themselves as more active, sociable, bold and determined, speak higher about their organizational skills and ability to get along with people, consider themselves influential, with a high level of willpower and a sense of humor. The self - esteem of non-resident teenagers is not so high. They are not so confident in their abilities and are almost not motivated to compete. However, the lack of assertiveness and activity in relationships with classmates, absolutely does not mean that any of the teenagersneliderov does not want to take a higher position in the class.

The inability or inability to achieve due to any circumstances a satisfactory situation for a teenager leads to various violations in educational activities, a decrease in academic performance, a manifestation of indiscipline, up to the Commission of offenses. Such influence of the sociometric status of the teenager in a class on his school life is defined, first of all, by features of personal development in this age period which is accompanied by the increased conformity of the child in relation to peers.

In addition, of particular importance in establishing effective relationships with classmates have certain individual and psychological characteristics of the personality of a teenager. Most of those who have difficulty communicating have qualities that block successful interpersonal interaction. These qualities are the following groups, which are due to:

- natural and genotypic characteristics (impulsiveness, shyness, instability);

- characterological features (indecision, uncertainty, isolation, closeness, assertiveness, conflict, indifference, cynicism);

- family orientation in relation to others (unformed communication skills based on poorly developed reflection).

Thus, conflicts between students at school arise, including due to misconduct, violations of generally accepted norms in the behavior of students. The norms of behavior of students in school are developed in the interests of all students and teachers. When they are observed, it is meant to reduce to a minimum the 
contradictions in school groups. Violation of these norms, as a rule, leads to infringement of someone's interests. The clash of interests is the basis for the conflict.

Interpersonal relationships of adolescents that arise spontaneously or organized by adults have clearly expressed age characteristics.

The phase of individualization is characterized by the refinement and development of ideas about yourself-the formation of the image of «I $»$. In comparison with primary school, children develop selfawareness and expand contacts with their peers. Participation in the work of various public organizations, interest groups, sports sections brings a teenager into the orbit of broad social ties. The development of role-based relationships is combined with the intensive formation of personal relationships, which from this time acquire a special significance [14].

Relationships with peers become more selective and stable. While preserving the highly valued properties of the «good friend», the role of the moral component in mutual evaluations increases. Moral and volitional characteristics of the partner become the most important basis of preferences. The status of the individual is most closely related to the volitional and intellectual properties of the student. Peers who are distinguished by their readiness and ability to be a good companion are highly appreciated. Kindness, as in primary school, remains one of the leading grounds for interpersonal choice.

It was revealed that «preferred» and «rejected» teenagers in the class differ in different orientation systems. «Preferred» is more focused on joint activities. When they realize the threat of loss of status, their strategy of behavior becomes active and activity becomes more intense, purposeful, organized. Students with an unfavorable position in the classroom are fixed mainly on relationships with peers. In the event of a threat to their already disadvantaged position in the group, they react affectively to the situation and are even ready to completely break off relations with their peers. The importance of emotional connections in peer groups is so great that their violations, accompanied by persistent States of anxiety and psychological discomfort, can be the cause of neuroses.

The need to communicate with peers, which can not be replaced by parents, occurs in children very early and increases with age. The behavior of adolescents is inherently collective-group.

And so the most important aspect of the social position of a teenager is the awareness of his Self, which is manifested in the formation of self-esteem, in relationships with peers and adults, in an increased interest in their own personality and the need to assess their personal qualities.

There is one of the main contradictions of this age-between the increased sense of independence, adulthood and social capabilities of the teenager.

There is a crisis situation that the teenager is trying to overcome. The main difficulty in this case is to find the lack of inner self-confidence in the teenager, clear self-awareness and self-respect, which make a person able to act independently and competently (in some cases, defending the right in spite of the resistance of others, and in others-calmly, without stubbornness accepting their requirements and norms of society).

Recently, there have been great changes in social life, science, and education. The requirements imposed on the school include, first of all, the need to form an active and self-acting personality capable of living in a legal state and civil society. This is a moment of respect and interest in the inner world of man, his individual characteristics and capabilities. Interest in the inner world of the child, the recognition of its value by society requires teachers to rethink teaching practice, taking into account the achievements of psychology and the development of new promising areas of development of school education in Russia, which include pedagogical conflict.

For pedagogical conflictology, development theories focused on revealing the contradictory, dialectical nature of the child's development are especially important. This development includes the immanence of conflict situations in the educational process. In social psychology, when analyzing interpersonal conflicts, it is customary to discuss their structure, dynamics of development, functions and causes of their occurrence, as well as possible options for their resolution. Speaking about the psychological structure of the conflict, usually distinguish the conflict situation and incident.

The conflict situation is an objective basis of the conflict, fixing the emergence of a real contradiction in the interests and needs of the parties. The presence of a conflict situation does not mean the interpersonal conflict itself: the existing contradiction may not be realized by the participants of the interaction for some time.

The dynamics of the conflict is in full accordance with its structure: the emergence of an objective conflict situation; awareness of the conflict; conflict actions; conflict resolution. 
Speaking about interaction in a conflict situation, we note that the study of changes in the nature of human interaction allows us to identify some points that act as determinants of subsequent patterns of behavior. There are three phases that determine the development of interpersonal relations in a conflict situation.

The first phase is related to the assessment of the situation as a conflict. The moment of awareness of the situation as a conflict is extremely important, because it itself becomes a mechanism that forms patterns of behavior that can in a certain way structure the interaction in this state.

The second phase is related to the choice of a strategy that structures interpersonal interaction in a conflict situation. Actualization of certain actions in a conflict situation is associated with a specific combination of objective and subjective factors. In this phase of interaction, each of the participants forms a certain line of behavior, which is later formed as a General strategy.

The third phase is related to the choice of action within the overall strategy of interaction. At this stage of the conflict development, the personal characteristics of the participants in the interaction play a special role.

Psychological signs of interpersonal conflict are:

- actualization of needs that acquire a dominant value for the individual;

- high psychological tension of subjects of conflict relations;

- reduced control over affective States;

- stereotypical behavior, thinking, statements;

- a comparative assessment of the values of their own and others in their favor;

- formation of a negative attitude to the perception of the opponent;

- transfer of conflict relations from one area of interaction to another, from personal to business.

Conflict has both positive and negative social functions. The positive or negative impact of conflict is largely due to the social system. In freely structured groups, where conflict is considered the norm and there are various mechanisms for its resolution, conflict usually contributes to great vitality, dynamism and receptivity to progress. In a totalitarian social group, conflict is not recognized in principle, and the only mechanism for resolving it is suppression by force. The suppressed conflict becomes dysfunctional, leading people to disintegration, aggravation of old and emergence of new contradictions [14].

Adolescence is the most stressful in terms of interpersonal conflicts. The specifics of the dynamics of adolescent interpersonal conflicts are as follows:

- awareness of the conflict is not mandatory;

- conflict actions are often acute and direct.

Can't find what you need? Try the literature selection service.

- awareness of the conflict, as a rule, is not associated with the awareness of the internal position of his and the opponent.

Pedagogical analysis of the constructive potential of the conflict covers all the main areas of behavior and consciousness of a teenager. A.K. Markov refers to them:

- dynamics of contradictions, the development of which determines the neoplasms of adolescence;

- character of conflicts, conditions of interaction of the teenager with the world of teachers as individuals;

- pedagogical approach that determines the attitude of the teacher to the conflict, the possibility of pedagogical theories and methods in the transformation of spontaneously arising conflicts in developing, where the teenager manifests itself as a subject of activity and self-determination [9].

The personality does not exist by itself, its inner world, its education is a complex and long process of interaction of the child in the system of social dependencies and relationships, in which the child plays an equal role with the adult in their own development.

The Central neoplasm of adolescence is the «feeling of adulthood». This orientation toward adulthood is an important component that determines the behavior of a teenager in interpersonal conflict. T.V. Dragunova distinguishes three types of adulthood (Tab. 1). 
Types of adulthood that determine the behavior of a teenager in an interpersonal conflict

\begin{tabular}{|l|l|}
\hline \multicolumn{1}{|c|}{ Types of adulthood } & \multicolumn{1}{c|}{ Signs of adulthood } \\
\hline Imitation of adulthood & $\begin{array}{l}\text { Smoking, alcohol consumption, the desire for adult fashion in clothes, hair, } \\
\text { cosmetics, ways to relax. }\end{array}$ \\
\hline Social maturity & $\begin{array}{l}\text { Occurs in the conditions of cooperation between a child and an adult in dif- } \\
\text { ferent activities, where the teenager takes the place of an adult assistant. This } \\
\text { is usually observed in families experiencing difficulties, where in fact the } \\
\text { teenager occupies the position of an adult. }\end{array}$ \\
\hline Intellectual adulthood & $\begin{array}{l}\text { Expressed in the desire of a teenager to know something and be able to really. } \\
\text { This stimulates the development of cognitive activity, the content of which } \\
\text { goes beyond the school curriculum }\end{array}$ \\
\hline
\end{tabular}

In addition, the formation of their own system of assessments and values, the need to have a personal point of view plays an important role in the creation of conflict situations by adolescents [11].

Communication with peers is the leading activity at this age. It is here that the norms of social behavior and morals are mastered, and the relations of equality and respect for each other are established. This makes it possible to develop special psychological and pedagogical methods of adolescent development, based on the features of interpersonal communication of the child, immanently including the ability to protect their norms in a conflict situation.

The main thing for a teenager at school is communication, in which the assimilation of moral norms takes place, the system of moral values is mastered. The assimilation of a moral model by a teenager occurs when he performs real moral actions in situations that are significant for him, and among them, actions in a conflict situation are especially significant.

Children's collective becomes a system of purposeful educational relations, when it is an environment for the implementation of social requirements for the individual and at the same time-its public selfexpression and self-affirmation.

Another reason that affects the sharp increase in the number of conflicts in adolescence is due to the expansion of the circle of communication between a teenager and teachers [13]. Different styles of behavior of teachers, different attitudes to students, different levels of professionalism and qualifications can be perceived by teenagers as a threat to their self-image.

Conflicts in the field of discipline can often occur due to the fault of teenagers who are not able to restrain their energy during the lesson or simply want to harm an unloved teacher.

A widespread cause of pedagogical conflict situations is the process of assessing the knowledge, skills and abilities of adolescents. In adolescents, increased criticality, there is the ability to independently analyze the level of response.

What is new here is that by comparing the actions of different subject teachers, students can independently use the principles of rating one of them as a certain criterion. If the identified criteria for evaluating teachers 'knowledge, skills and abilities differ significantly, this can lead not only to a conflict in the system of relations «teacher-student», but also «teacher-teacher». The lack of uniform requirements for marking is fraught with conflicts.

N.V. Grishina identifies two main types of pedagogical influence on the personality of a child in a state of interpersonal conflict-direct and indirect.

Direct influence is understood as a direct appeal to the subject in order to present him with any requirements or proposals. This impact on adolescents is limited due to the fact that interpersonal conflict occurs, as a rule, outside the boundaries of the educational process. With indirect influence, the teacher directs his efforts to the environment of the student, aiming to change the circumstances of life, the rules of interaction, affecting the formation of the reference group of the person of interest.

The influence exerted by the teacher on the course of the conflict can be purposeful. Purposeful influence is the result of specially organized influence by the teacher. Such influence is deliberate, deliberate, planned. Non-targeted influence is associated with the personal characteristics of the teacher's style.

Having considered the structure of the conflict, some causes of conflicts, we can offer the most General recommendations for their resolution. 
1. To recognize the existence of a conflict, that is, to recognize the existence of opposite goals, methods of opponents, to determine the participants themselves.

2. Determine the possibility of negotiations.

3. Agree on the negotiation procedure.

4. Identify the range of issues that constitute the subject of the conflict.

5. To develop solutions.

6. Make an agreed decision.

7. Implement the decision in practice.

Let's name some ways of psychological and pedagogical conflict resolution, the creative use of which makes them unique in the work of teachers. In situations of empty conflict, joke and humor are effective, which defuse the situation, extinguish and eliminate the incident. In some cases, to resolve the conflict, the teacher-psychologist resorted to the method of the arbitration court-an appeal to a third independent person.

Mediation of the teacher-psychologist in the conflict among teenagers is a way to resolve it. It should be noted that the very concept of «mediator» is widely used to describe any third-party intervention in the settlement of disputes. In this case, the emphasis is on the organization of meaningful assistance to the conflicting parties. This understanding of mediation and organisation in accordance with it, the involvement of a psychologist in interpersonal conflict adolescents has a significant correctional capacity because it does not just changes the positions of the conflict parties against each other and the object of the conflict, but, above all, contributes to the opponents of a reflexive attitude towards themselves and their abilities, which in turn becomes the basis for the transition to new forms of social behavior.

The main mechanism of mediation between conflicting teenagers is to establish a special type of relationship with the participants of the conflict - a friendly, interested, trustworthy, but neutral attitude.

Compromise can also be a psychological and pedagogical approach to conflict resolution, when the parties come to an agreement on the basis of mutual concessions.

Mutual analysis also helps in conflict resolution. This form requires the creation of an atmosphere of goodwill and trust, the manifestation of the teacher's sincere interest in establishing relations.

In some cases, it is appropriate to present the nascent conflict in grotesque forms, so that the contradictions become visible to all. Then the resolution of the conflict acts as a process of education, since all children are included in it, and they themselves make a choice between alternative solutions [14].

Difficult life pedagogical situations require from the teacher extraordinary, non-standard solutions and methodological techniques, which encourages thinking educators to constant creativity, creation and application of new tactical ways to interact with teenagers.

\section{References}

1 Argyle M., Furnham A. Sources of satisfaction and conflict in different long-term relationships / M. Argyle, \& A. Furnham // Journal of Marriage and the Family. - 1982. - 45. - 481-493.

2 Cooper C.R. The role of conflict in adolescent-parent relation ships / C.R. Cooper; In M.R. Gunnar \& W.A. Collins (Eds.), Minnesota symposia on child psychology. - Vol. 21. - P. 181-187. — Hillsdale, NJ: Erlbaum, 1988.

3 Belsky J. Childhood experience, interpersonal development, and reproductive strategy: An evolutionary theory of socialization / J. Belsky, L. Steinberg, P. Draper // Child Development. — 1991. — 62. — 647-670.

4 Berscheid E. Interpersonal attraction / E. Berscheid; In G. Lindzey \& E. Aronson (Eds.), Handbook of social psychology. P. 413-484. - New \brk: Random House.(1985).

5 Fitzpatrick M.A.. You always hurt the one you love: Strategies and tactics in interpersonal conflict / M.A. Fitzpatrick, J. Winke // Communication Quarterly. — 1979. - 27. - 3-11.

6 Levya R.A. Compromise formation in social conflicts: The influence of age, issue, and interpersonal context / R.A. Levya, H.G. Furth // Journal of Youth and Adolescence. — 1986. - 15. - 441-452.

7 Selman R.L. The development of interpersonal competence: The role of understanding in conduct / R.L. Selman // Developmental Review. - 1981. - 1, 401-422.

8 Steinberg R.J. Resolving interpersonal conflicts: An analysis of stylistic consistency / R.J. Steinberg, D.M. Dobson // Journal of Personality and Social Psychology. — 1987. - 52. - 794-812.

9 Анцупов А.Я. Альбом схем по психологии конфликта / А.Я. Анцупов, А.И. Шипилов. — М.: ВУ, 1996.

10 Драгунова Т.В. Проблема конфликта в подростковом возрасте / Т.В. Драгунова // Психология конфликта: хрест. / сост. Н.В. Гришина. - СПб.: Питер, 2001. - С. 328-348.

11 Прокофьева Н.С. Межличностные конфликты в подростковом возрасте / Н.С. Прокофьева, Т.Г. Бобченко // Молодой ученый. - 2017. — № 37. - С. 109-112. 

$110 \mathrm{c}$.

12 Агеев В.С. Межгрупповое взаимодействие. Социально-психологические проблемы / В.С. Агеев. - М., 1990. -

13 Березюк Ю.В. Подготовка будущего учителя к применению метода моделирования педагогических ситуаций в учебном процессе / Ю.В. Березюк // Карельский науч. журн. - 2013. — № 1. - С. $12,13$.

\title{
3.К. Кульшарипова, С.Н. Токабаева, Л.С. Сырымбетова
}

\section{Жасөспірім кезіндегі тұлғааралық қақтығыстар}

\begin{abstract}
Бүгінгі таңда мектеп жанжалдары мәселесі өте өзекті және көптеген адамдардың назарын аударуда. Оқушылардың дүниетанымдық құндылықтарын қалыптастыру, өзіндік мінез-құлық үлгілерін дамыту, сыныптастар арасында олардың «орнын» белгілеу көбіне шиеленістерге әкеледі. Қарамақайшылықтар келіспеушілік аймағы болған кезде пайда болады, яғни келіспеушіліктен туындаған дау, факт немесе мәселе. Бұл мәселені шешу әлеуметтік-педагогикалық саланы және психологиялық қызмет саласын интеграциялау технологиясын зерттеу процесінде бірқатар мақсаттарға қол жеткізуді көздейді: теориялық білімді педагог-психологтардың кәсіби қызметін жүзеге асыру үшін қажетті және жеткілікті мөлшерде игеру. Жасөспірім үшін қақтығыстарға деген көзқарасты өзгерту іс жүзінде олардың өмірге деген көзқарасын өзгертуді білдіреді. Жанжал - бұл адам өмірінің маңызды және болдырмайтын құбылысы, өйткені адамның өзара әрекеті бар жерде жеке ұнату және ұнатпау ықтималдығы бар. Бұл келісімдер және жеке адамдар мен топтар арасындағы келіспеушіліктер оларды жанжалға алып келеді. Жанжалдар конструктивті де, бұзушы да емес, бірақ оларды шешу жолдары оларды жағымды немесе теріс етеді. Мектептерде басқа адам ұйымдары сияқты қақтығыстың бір түріне ұшырайды. Жанжалды басқару үшін түрлі қақтығыстарды басқару стратегиясы қабылданады. Олардың ішіндегі ең маңыздылары - делдалдық, келіссөздер, жол бермеу, ынтымақтастық. Біз нақты жағдайды, мінез-құлық пен ойлауды өзгертетін жұмыс шешімін іздеуіміз керек.
\end{abstract}

Кілm сөздер: жасөспірім, қолдау және түзету, жаңа нормалар мен ережелерді әзірлеу, жанжал, тұлғааралық қатынастар.

\section{3.К. Кульшарипова, С.Н. Токабаева, Л.С. Сырымбетова Межличностные конфликты в подростковом возрасте}

\begin{abstract}
Конфликт является важным и неизбежным явлением в человеческой жизни, потому что там, где есть человеческое взаимодействие, есть возможность личных симпатий и антипатий. Эти соглашения и разногласия между людьми и группами приводят их к конфликту. Конфликты не являются ни конструктивными, ни разрушительными, но способы их разрешения делают их позитивными или негативными. Школы, как и другие человеческие организации, подвержены той или иной форме конфликта. Стратегии управления конфликтами принимаются для различных конфликтов. Наиболее важными из них являются посредничество, переговоры, профилактика, сотрудничество. На сегодняшний день проблема школьных конфликтов очень актуальна и привлекает внимание многих. Становление мировоззренческих ценностей учащихся, выработка своих образцов поведения, утверждение своего «места» среди одноклассников часто приводят к возникновению конфликтов. Конфликт возникает тогда, когда есть зона разногласий - предмет спора, факт или вопрос, вызвавший разногласия. Решение этой задачи предполагает достижение ряда целей в процессе изучения технологии интеграции социально-педагогической сферы и сферы психологической службы: овладение теоретическими знаниями в объеме, необходимом и достаточном для реализации профессиональной деятельности педагоговпсихологов. Изменить отношение к конфликтам для подростка практически означает изменить взгляд на жизнь. Нужно искать работающее решение, которое изменит конкретную ситуацию, поведение и мышление.
\end{abstract}

Ключевые слова: подросток, поддержка и коррекция, освоение новых норм и правил, конфликт, межличностные отношения.

\section{References}

1 Argyle, M., \& Furnham, A. (1982). Sources of satisfaction and conflict in different long-term relationships. Journal of Marriage and the Family, 45, 481-493.

2 Cooper, C. R. (1988). The role of conflict in adolescent-parent relation ships. In M.R. Gunnar \& W.A. Collins (Eds.). Minnesota symposia on child psychology, Vol. 21, 181-187. Hillsdale, NJ: Erlbaum.

3 Belsky, J., Steinberg, L., \& Draper, P. (1991). Childhood experience, interpersonal development, and reproductive strategy: An evolutionary theory of socialization. Child Development, 62, 647-670. 
4 Berscheid, E. (1985). Interpersonal attraction. In G. Lindzey \& E. Aronson (Eds.), Handbook of social psychology, $413-484$. Newlbrk: Random House.

5 Fitzpatrick, M.A., \& Winke, J. (1979). You always hurt the one you love: Strategies and tactics in interpersonal conflict. Communication Quarterly. 27, 3-11.

6 Levya, R.A., \& Furth, H.G. (1986). Compromise formation in social conflicts: The influence of age, issue, and interpersonal context. Journal of Youth and Adolescence, 15, 441-452.

7 Selman, R.L. (1981). The development of interpersonal competence: The role of understanding in conduct. Developmental Review, 1, 401-422.

8 Steinberg, R.J., \& Dobson, D.M. (1987). Resolving interpersonal conflicts: An analysis of stylistic consistency. Journal of Personality and Social Psychology, 52, 794-812.

9 Antsupov, A.Ya., \& Shipilov, A.I. (1996). Albom skhem po psikholohii konflikta [Album schemes on the psychology of conflict]. Moscow: VU [in Russian].

10 Dragunova, T.V. (2001). Problema konflikta v podrostkovom vozraste [The problem of conflict in adolescence]. Psikholohiia konflikta - Psychology of conflict, 328-348 / comp. N.V. Grishina. Saint Petersburg: Piter [in Russian].

11 Prokofieva, N.S., \& Bobchenko, T.G. (2017). Mezhlichnostnye konflikty v podrostkovom vozraste [Interpersonal conflicts in adolescence]. Molodoi uchenyi - Young scientist, No. 37, 109-112 [in Russian].

12 Ageev, V.S. (1990). Mezhhruppovoe vzaimodeistvie. Sotsialno-psikholohicheskie problemy [Intergroup interaction. Sociopsychological problems]. Moscow [in Russian].

13 Berezyuk, Yu.V. (2013). Podhotovka budushcheho uchitelia k primeneniiu metoda modelirovaniia pedahohicheskikh situatsii $\mathrm{v}$ uchebnom protsesse [Preparing the future teacher for the application of the method of modeling pedagogical situations in the educational process]. Karelskii nauchnyi zhurnal - Karelian Scientific Journal, No. 1, 12-13 [in Russian]. 